DOI: $10.30519 /$ ahtr.969226

Advances in Hospitality and Tourism Research (AHTR)

\title{
EXPECTATIONS OF DOMESTIC WOMEN BUSINESS TRAVELERS FROM HOTEL ACCOMMODATION: A PERSPECTIVE OF HOTEL MANAGERS
}

\author{
Gagandeep NARULA ${ }^{1}$ \\ GDGoenka University, India \\ ORCID: 0000-0002-5898-6648
}

\author{
Sarah HUSSAIN \\ Department of Tourism and Hospitality \\ Management, Jamia Millia Islamia, India \\ ORCID: 0000-0003-0161-4699
}

\author{
Tanuja KAUSHIK \\ Student Welfare and International Relations, \\ GDGoenka University, India \\ ORCID: 0000-0003-2554-6926 \\ Fred DEMICCO \\ School of Hotel and Restaurant Management, \\ Northern Arizona University, Arizona, USA \\ ORCID: 0000-0002-7768-686X
}

\begin{abstract}
The objective of this paper is to ascertain the perception of hotel managers concerning the expectations of domestic women business travelers (DWBT) through qualitative analysis. This research was performed using synchronous focus group discussions (FGDs) virtually on Microsoft Teams. Participants belonged to the management of 5-star hotels in Delhi and Gurugram (cities in the National Capital Region, India). Transcripts were analyzed thematically using NVivo (Release 1.0) software. The authors have proposed seven core themes associated with female symbols of expectations looked forward to by DWBT from their hotel stay. These are guest room as the expectation of servicescape and design, hotel services as the expectation of comfort, amenities as the expectation of quality and value, hotel security as the expectation of assurance and trust, augmented specials being the expectation of personalization, selection triggers being the expectation of convenience and suitability, and customized meal requirements being the expectation of health and wellbeing. Hospitality marketers may apply strategic planning and decision-making to devise focused communication strategies to accomplish the expectations of this segment. To the best of our knowledge, this research is the first to break new ground to assess findings using synchronous FGDs for understanding the expectations of DWBT from the management perspective.
\end{abstract}

\section{Article History}

Received 9 July 2021

Revised 26 September 2021

Accepted 4 January 2022

Published online 25 Feb. 2022

\section{Keywords}

domestic women business travelers synchronous focus group discussion management perspective hotel selection perceptions expectations

\footnotetext{
${ }^{1}$ Address correspondence to Gagandeep Narula, Research Scholar, GDGoenka University, Gurugram, Haryana, India. E-mail: gagan@bcihmct.ac.in
} 


\section{INTRODUCTION}

Expectations are beliefs accompanying service provision, serving as a benchmark against which the actual service performance is assessed (Zeithaml et al., 2006). Hotel guests evaluate service quality based on their perceptions. Quality can be perceived by hotel guests as "fitness of use, performance, service, features, grade, warranty, price, reputation, degree of preference and, degree of excellence" (Tewari, 2009). Quality enhancement measures require managers to differentiate the expectations of guests' segment-wise. Hotels falling short of guests' expectations face a higher level of perceived risk with a decline in the perceived service quality (Wu et al., 2012).

The purpose of a hotel visit has a profound impact on the guest's expectations (Umasuthan et al., 2017). Leisure and business travelers, the two key market segments catered by hotels, differ remarkably in their expectations (Rohani et al., 2017). Hotel marketers need to comprehend the difference in guest expectations based on trip purpose. Consequently, positioning strategies need to be designed as per the needs of the target market. Guest satisfaction can be achieved by meeting the desired level of guest expectations which implies that the lesser the gap between management perceptions and guest expectations, the higher the satisfaction (Hussain, 2017).

Furthermore, the formation of hotel expectations varies according to gender (Ariffin \& Maghzi, 2012). Cobanoglu et al. (2003) revealed significant differences in the attributes important for male and female business travelers. Hotel marketers need to design strategies from a gendered perspective as the micro-segment of women business travelers differs from the males in hotel selection criteria and expectation formation. An increase in the women-business travelers (Brownell, 2011) makes it vital for hotel managers to incorporate gender-based segmentation for strategizing services and promotions since women travelers are a lucrative market segment (Juwaheer, 2011).

A research report stated that $85 \%$ of the purchase decisions are taken by $47 \%$ of the women who pursue work-based travel (Garcia, 2014). The growth of a specific market segment leads to many novel developments within the hospitality sector. Identifying the exact needs of women business guests supports directing the hotel's resources and facilities in a channeled way to retain and attract them. Survival in this competitive hospitality market is possible only if the management's perception conforms to the expectations of this ever-growing segment of women. 
Guest expectations and perception in the hotel industry is a majorly addressed research topic (Deng et al., 2008; Hussain \& Khanna, 2019; Lockyer, 2002; Mohsin et al., 2019). Cetin and Walls (2016) affirmed the awareness possessed by the hotel managers for creating exceptional guest experiences concerning strategies designed for differentiation, generating positive word of mouth, and guest loyalty. Brownell (2011) re-confirmed that the perceptions of hotel managers concerning the preferences of women travelers are a vital link in the sequence of guest satisfaction. The responsibility for creating an environment preferred by women guests from their stay in a hotel remains on the managers, and incorporating their viewpoint is essential for creating an experiential stay for the women guests. Employee perception for fostering guest experience is equally crucial for effective brand management (King \& Grace, 2008). However, scant research exists on the expectations of DWBT from the perception of hotel management, specifically in the milieu of the Indian hotel sector, using an online synchronous internet-based focus group. Hence, this study tries to address this research gap using a phenomenological approach through qualitative analysis. This research makes a meaningful contribution to the already existent literature by conveying the seven symbols of expectations for DWBT from their hotel accommodation. Performing synchronous focus groups with the management of five-star hotels located in Delhi and Gurugram has helped in accomplishing the same. Findings reveal the opinion of participants significant to DWBT for selecting hotel accommodation.

In the following sections of the research study, a brief literature review has been presented followed by the research design and methodology. The findings obtained have been discussed in view of the reviewed literature. Theoretical and practical implications, limitations, and future research ideas are presented in the final section of the study.

\section{LITERATURE REVIEW}

\section{Expectations of Women Business Guests from Hotel Accommodation}

Business travel empowers women (Newth, 2009), and being in a powerful state enhances the desire for exclusivity (Kim, 2018). A dramatic rise in the women business traveler segment points towards addressing the needs of this segment (Brownell, 2011). Gender also plays a predominant role in the emergence of expectations and the perceived importance of accommodation attributes specific for business travel (Meng \& Uysal, 2008). 
Features such as promotion, previous encounters, individual requirements, goodwill of service providers have a determining effect on guest expectations (Michel, 2001). The consumer decision-making process entails a three-step sequence where consumers identify the needs they want to be fulfilled, search for information, and finally evaluate all available alternatives (Blackwell et al., 2006). The veteran business travelers are seasoned professionals and assign significant value to hotel attributes. Effective communication of hotel services and products with preferences influences their decision-making process.

Well-maintained hotels are a prime factor for selection considered by the niche segment of businesswomen guests. Quality hotel accommodations offering comfort, safety (Hao \& Har, 2014), and satisfaction to women business travelers are the core expectations forming the basis of hotel selection by women (Juwaheer, 2011). Moreover, female guests hailing from Asia place significance on the concept of women-only floors (Chan \& Lam, 2013). Women expect reassurance from hotels concerning security features for a safe stay (Chan \& Lam, 2013; Cobanoglu et al., 2003) and are willing to pay more for these enhanced features (Feickert et al., 2006). Provision of clean guestrooms with comfortable sleeping facilities (Gumaste, 2019; Liu et al., 2013) and hygienically maintained guest washrooms (Tsai et al., 2011) are of utmost importance for single women business travelers. Women also expect hotel staff to render services with a personal touch with an excellent variety of in-room facilities and amenities (Gumaste, 2019). Convenient transport and a strategic location helps a hotel attract female customers traveling (Liu et al., 2013).

Safety and security with cleanliness and hygiene are of utmost importance and form basic expectations for women business travelers (McCleary et al., 1994). Designing guestrooms to offer maximum relaxation by providing peaceful and quiet bedrooms with comfortable bedding and pillows can augment the experience of women guests traveling for work (Mao et al., 2018). Proficient front-office services (Chan \& Wong, 2006) and behavior of hotel staff are equally significant in creating a positive experiential and satisfactory hotel stay (Sánchez-Franco et al., 2018). Trained employees sensitized towards the needs of women business guests and adept at handling their requests promptly with utmost care are a must for generating satisfaction.

Food has an equivalent impact on the hotel choice made by business travelers. Women on a domestic business trip expect hotels to provide healthy food and beverage options in the room service menu (Chen, 2019). 
DWBT prefer maintaining a healthy lifestyle while traveling and seek quality meals from the hotels.

The literature shows that intangible aspects of service quality for creating an experiential stay (Sánchez-Franco et al., 2018), a prime hotel location (Masiero et al., 2019; Tsai et al., 2011), and a favorable price on offer (Kim et al., 2020; Lockyer, 2005a) act as key trigger points for selecting a hotel for a business stay. To limit the in-city travel time to the workplace, the proximity of a hotel plays an important role. Proximity is also associated with work productivity since the time saved from traveling can be directed towards the procurement of work goals.

Women are generous spenders who are willing to pay (Garcia, 2014) for the services delivered to them (Juwaheer, 2011). Apart from hotel features, positive emotional responses influence women's purchase and selection decisions (Brownell, 2011). The fact that women guests show greater dissatisfaction than male hotel guests (Salleh et al., 2016) can be attributed to their attention towards social and interpersonal interaction with hotel employees during moments of truth (Iacobucci \& Ostrom, 1993). Extraordinary and memorable experiences for women travelers need to be emphasized upon by hotel staff. Satisfaction can be engendered through fulfilling and exceeding the expectations of domestic women business travelers. If the expectations of DWBT from hotels are not met adequately, this may impact their decision-making for future reservations. Consequently, the hotels may continue to delight the DWBT by creating personalized and luxurious experiences.

\section{Perception of Hotel Managers for Women Business Guests}

Investigating employee perception has become increasingly important for managing a hotel brand (King \& Grace, 2008; Tsang et al., 2011). The highly competitive nature of the hotel sector makes it crucial for the managers to be thoughtful towards the business facets significant to their guests for meeting their expectations. Intense competition and proliferation of niche market segments necessitate an astute understanding by hotel managers for taking accurate decisions regarding the apt channelization of their resources (Hu \& Trivedi, 2020).

For successful delivery of service, the expectations of guests and perceptions of hotel management must be concurrent. The magnitude of the gap increases between the two when there is a lack of knowledge (Luk \& Layton, 2002). Previous studies have identified gaps prevailing between the 
perceptions of hotel employees and expectations of business guests (Chan \& Lam, 2013; Lockyer, 2002). Hussain (2017) also established that there were differences between the hotel employee's perception of guest expectations and the guests' actual expectations from the 5-star deluxe hotels of Delhi. This challenge could be managed by training employees regularly. Meticulous planning and consideration by the hotel management is significant for monitoring the service quality through appropriate resource allocation. The purpose of hotel management is to provide guest satisfaction, which can be achieved when there is correct wisdom about guest perception regarding service quality (Hussain \& Khanna, 2019). Cetin (2020) argued that experience is a better predictor of guest satisfaction and loyalty when compared to service quality as the quality of service provides a meager fulfillment of guest expectations. The author stated that even though service quality and experience are the chief antecedents vital for the success of an organization, an exceptional guest experience significantly impacts customer loyalty and satisfaction.

Perception of hotel managers regarding the preferences of women business travelers is a key component vital for satisfaction. Hoteliers need to amalgamate hotel facilities, services, and amenities for a holistic stay experience for the female business segment. This is essential for creating the ideal affective environment favored by women business guests. Managers need to work continuously for making the women business guests feel valued and cared for, by reinforcing the feeling of safety and comfort, and through embodying the feeling of empowerment.

Hotel managers need to ensure that service quality delivered through appropriately designed standards results in positive guest experiences (Blesic et al., 2011). Clarity regarding the tangible and intangible hotel features wished for by women travelers on domestic travel also need to be better understood as guests evaluate their hotel experience based on varied need-based aspects.

\section{RESEARCH DESIGN AND METHODOLOGY}

A qualitative research design with a phenomenological approach has been implemented in the study as the authors probed perceptions, understandings, points of view, conduct, and reasoning of hotel managers. The phenomenological approach was considered for the study since the perceptions regarding the expectations of DWBT (a phenomenon) by the hotel managers have been investigated. According to Lester (1999, p. 1), "the purpose of the phenomenological approach is to illuminate the 
specific, to identify phenomena through how they are perceived by the actors in a situation".

\section{Sampling and Data Collection}

The National Integrated Database of Hospitality Industry in India (NIDHI); was accessed for collecting data related to the listed five-star hotels in Delhi and Gurugram as these are a part of the National Capital Region, possessing a higher inventory of branded hotels. Moreover, Gurugram is a prominent commercial and business center in Northern India (Khanna \& Tyagi, 2019).

The five-star hotels in Delhi and Gurugram were selected using the total purposive sampling technique. Since the population of 5-star hotels in Delhi and Gurugram is forty-two, which is relatively small and is well defined, all the hotels were included in the research study. The authors contacted the human resource department of the hotels through e-mails. Only nine hotels responded to the e-mails sent and gave their consent for participation in the study.

Five-star hotels were selected for the study as luxury hotel employees are more aware of guest expectations (Hussain \& Khanna, 2019). Also, employees of five-star hotels are more connected with their guests than the four-star hotel employees (Seal et al., 2018). The objective of the study was explained to the human resource department of these hotels. Thereafter, the researchers were provided with the prospective participants' details. Using non-probability judgmental sampling, the researchers shortlisted forty-six participants based on certain qualities (Zikmund, 2003). The participants holding management positions in operations departments of Front Office, Housekeeping, Food and Beverage Services, and Food Production were chosen and approached.

Out of the forty-six, senior industry personnel contacted through emails, fifteen participants gave consent to participate in the virtual synchronous focus group discussions due to challenges of responsibility faced during adverse situations put forth by the pandemic for the hospitality sector. Keeping the Covid-19 pandemic situation in mind, online synchronous focus group discussion was considered to be safe. Virtual FGDs are time-saving and cost-efficient since participants can log in at a similar period from the convenience of their residence or place of work (Hennink, 2014). The conceptual generation of ideas in online FGDs is equivalent to the traditional focus groups for hospitality research. Also, the 
quality of ideas in terms of feasibility and novelty are similar (Richard et al., 2018).

The synchronous FGD was pursued with the help of Microsoft Teams by using text and audio-visual modes, unlike the asynchronous focus groups that are text-based only (Hinkes, 2021). Most hospitality professionals were already familiar with the software as it is user-friendly and is used extensively for online sessions. This qualitative stance of research was the most suited as critical insights could be generated from the same.

The questions were designed based on current literature available on women business travelers, their expectations, and perceptions of hotel managers. Gathering responses through open-ended questions enhances the flexibility of the participants for sharing their experiences and perceptions (Maguth \& Yamaguchi, 2020). Facilitating the analysis necessitated informing the respondents that there were no right or wrong answers, but different points of view (McIntosh \& Siggs, 2005). The focus group questions put forth during the discussion were classified under the following related topics:

i. Importance of the women business traveler segment to the hotels, the reasons behind targeting this particular market segment, and the benefits gained.

ii. The nature of expectations of DWBT from the hotels during their stay from the perception of the managers for all the four core hotel departments- housekeeping, front office, food \& beverage service, and food production; any department-specific requirements or any requests put forth by DWBT during the period of stay.

iii. Special provisions made available by the hotels keeping in mind the needs of DWBT along with exclusively designed standards.

iv. Factors responsible for the specific expectations of DWBT and the difference between their requirements from the other guests staying at the hotel.

The participants were informed beforehand, that the responses obtained would be kept anonymous and utilized only for academic research purpose and that they need not answer any particular question and were free to leave the session at any time. 


\section{Administration of Focus Groups}

The number of group sessions, for FGDs, has been a contradictory topic as there is no thumb rule for the same. Time, resources, the interest of the researcher, and the features of the study are a few other considerations for planning group meetings (Kitzinger, 1994). Three FGDs were conducted with four participants in each discussion. Three members could not join at the prescribed time because of unexpected professional accountabilities. Due to the pandemic, hotels operated with severe staff shortages, therefore three meetings were considered sufficient for the study. Synchronous FGDs conducted using the audio-visual mode should appropriately have 4 to 6 participants to prevent overcrowding of the screen in view (Lobe, 2017).

The FGDs lasted for approximately an hour and fifteen minutes and were led by the same moderator. Comprehensible focus groups last between 1 to 2 hours (Morgan, 1997).

\section{Focus Group Data Analysis}

The meetings conducted were recorded and downloaded using Microsoft Teams after obtaining prior consent from the respective participants. The downloaded recordings were transliterated verbatim within a single day after the conduct of the FGDs by the authors. Transcripts produced in word format from the downloaded recordings were imported and analyzed using Computer Assisted Qualitative Data Analysis Software (CAQDAS) NVivo (Release 1.0). The authors created nodes (Richards, 2005) for the hotel attributes defined by all the participants. The nodes were then linked with sources individually to identify the emerging patterns and concepts.

Thematic analysis resultant from the discussion of the industry practitioners leads to the generation of several key themes. The findings generated were validated through comparison with the previously established literature.

\section{Sample Characteristics}

Table 1 represents a summary of the participant profiles representing the four core departments of five-star hotels. All participants belonged to the management level in the hotels and had regular interactions with the guests. 
Narula et al.

Table 1. Participants' profiles

\begin{tabular}{|c|c|c|c|c|c|c|}
\hline $\begin{array}{c}\text { Participant } \\
\text { Codes \& Gender }\end{array}$ & Organization & Department & Designation & $\begin{array}{l}\text { Star Category } \\
\text { \& Region }\end{array}$ & $\begin{array}{c}\text { Age of } \\
\text { Participants }\end{array}$ & $\begin{array}{c}\text { Total Work } \\
\text { Experience (In years) }\end{array}$ \\
\hline P1 (M) & $\begin{array}{l}\text { Hospitality- } \\
\text { Hotels }\end{array}$ & $\begin{array}{l}\text { Food and } \\
\text { Beverage }\end{array}$ & F \& B Director & $\begin{array}{c}5 \text { Star / } \\
\text { New Delhi }\end{array}$ & 37 & 16 \\
\hline P2 (M) & $\begin{array}{l}\text { Hospitality- } \\
\text { Hotels }\end{array}$ & Housekeeping & $\begin{array}{l}\text { Director of } \\
\text { Services }\end{array}$ & $\begin{array}{c}5 \text { Star / } \\
\text { New Delhi }\end{array}$ & 38 & 17 \\
\hline P3 (F) & $\begin{array}{l}\text { Hospitality- } \\
\text { Hotels }\end{array}$ & Front Office & $\begin{array}{l}\text { Guest Services } \\
\text { Manager }\end{array}$ & $\begin{array}{c}5 \text { Star / } \\
\text { New Delhi }\end{array}$ & 38 & 15 \\
\hline P4 (M) & $\begin{array}{l}\text { Hospitality- } \\
\text { Hotels }\end{array}$ & $\begin{array}{l}\text { Food and } \\
\text { Beverage } \\
\text { Production }\end{array}$ & $\begin{array}{c}\text { Executive Pastry } \\
\text { Chef }\end{array}$ & $\begin{array}{l}5 \text { Star/ } \\
\text { New Delhi }\end{array}$ & 43 & 22 \\
\hline P5 (M) & $\begin{array}{l}\text { Hospitality- } \\
\text { Hotels }\end{array}$ & $\begin{array}{l}\text { Food and } \\
\text { Beverage }\end{array}$ & F \& B Manager & $\begin{array}{c}5 \text { Star / } \\
\text { New Delhi }\end{array}$ & 37 & 16 \\
\hline P6 (M) & $\begin{array}{l}\text { Hospitality- } \\
\text { Hotels }\end{array}$ & Housekeeping & $\begin{array}{c}\text { Executive } \\
\text { Housekeeper }\end{array}$ & $\begin{array}{c}5 \text { Star / } \\
\text { Gurugram }\end{array}$ & 31 & 11 \\
\hline P7 (M) & $\begin{array}{l}\text { Hospitality- } \\
\text { Hotels }\end{array}$ & Front Office & $\begin{array}{l}\text { Front Office } \\
\text { Manager }\end{array}$ & $\begin{array}{c}5 \text { Star / } \\
\text { New Delhi }\end{array}$ & 36 & 12 \\
\hline P8 (M) & $\begin{array}{l}\text { Hospitality- } \\
\text { Hotels }\end{array}$ & $\begin{array}{l}\text { Food and } \\
\text { Beverage } \\
\text { Production }\end{array}$ & Junior Sous Chef & $\begin{array}{c}5 \text { Star / } \\
\text { Gurugram }\end{array}$ & 30 & 7 \\
\hline P9 (F) & $\begin{array}{l}\text { Hospitality- } \\
\text { Hotels }\end{array}$ & Front Office & $\begin{array}{l}\text { Assistant Front } \\
\text { Office Manager }\end{array}$ & $\begin{array}{l}5 \text { Star / } \\
\text { Gurugram }\end{array}$ & 25 & 3 \\
\hline P10 (F) & $\begin{array}{l}\text { Hospitality- } \\
\text { Hotels }\end{array}$ & Housekeeping & $\begin{array}{l}\text { Assistant } \\
\text { Housekeeping } \\
\text { Manager }\end{array}$ & $\begin{array}{c}5 \text { Star / } \\
\text { Gurugram }\end{array}$ & 26 & 3 \\
\hline P11 (F) & $\begin{array}{l}\text { Hospitality- } \\
\text { Hotels }\end{array}$ & $\begin{array}{l}\text { Food and } \\
\text { Beverage }\end{array}$ & $\begin{array}{l}\text { Assistant Coffee } \\
\text { Shop Manager }\end{array}$ & $\begin{array}{c}5 \text { Star / } \\
\text { New Delhi }\end{array}$ & 29 & 5 \\
\hline P12(F) & $\begin{array}{l}\text { Hospitality- } \\
\text { Hotels }\end{array}$ & Front Office & Duty Manager & $\begin{array}{c}5 \text { Star / } \\
\text { Gurugram }\end{array}$ & 26 & 3 \\
\hline
\end{tabular}

\section{FINDINGS AND DISCUSSION}

For a resourceful and rigorous interpretation of findings, data was analyzed using NVivo (Release1.0) software. The synchronous FGD resulted in a thirty-one-page transcript which was checked for accurateness and imported into the NVivo software for thematic analysis. Even though NVivo aided the researchers in the coding process, the authors manually coded the data for ensuring accuracy and possessing a better understanding (Auld et al., 2007). The expectations of DWBT perceived by managers were highlighted and color-coded in the transcript followed by categorizing them under different dimensions in the manual coding process.

\section{Thematic Analysis}

Thematic analysis can be defined as an approach, for the identification, analysis, and creation of thematic patterns within the data. The process permits the creation of preliminary and initial coding groups (Braun \& Clarke, 2006). Identification of recurring themes from the data generates valuable and methodical findings. The open-ended questions designed for the focus group allowed participants to talk about a varied and comprehensive range of dimensions related to the expectations of women business travelers from their stay at a five-star hotel. The researchers 
reviewed the coded data to determine if a logical pattern was recognizable (Thyme et al., 2013). Common features, patterns, and sub-themes were extracted and grouped under the most significant clusters (Creswell, 2007). The common features and patterns were finally organized according to the literature reviewed (Bryman, 2012) and the core themes extracted from the transliterated data. A total of 79 dimensions (presented in Table 2) were identified from the transcripts which were grouped under seven major themes (presented in Table 3). Findings of the study are also presented with augmentation and quotations from the responses received from managers during the FGD (inductive analysis). These results were also corroborated by theory and discussions from the existent literature (deductive analysis) (Gummesson, 2000).

The businesswomen know that the services rendered to them are symbols of recognition that help fulfill their needs (Urry, 1991). These symbols are consumed, and the providers of these symbols must ensure the assurance ingrained in the symbol. The authors have categorized every theme as a female symbol of expectation. These seven symbols of expectations (Table 3) are what DWBT look forward to, from their accommodation at five-star hotels and play a pivotal role in their stay.

Table 2. Sub-themes and codes

\begin{tabular}{|c|c|c|c|}
\hline $\begin{array}{l}\quad \text { Theme: Guest Room } \\
\text { Codes: } \\
\text { Guestroom Design and Ambiance } \\
\text { Guestroom décor } \\
\text { Guestroom design } \\
\text { Good architecture and design } \\
\text { Lighting in the guestroom } \\
\text { Proper working space } \\
\text { Writing table and comfortable chair. } \\
\text { Guestroom bed is the focal point. } \\
\text { Spacious guestrooms. } \\
\text { Design of guest bathroom } \\
\text { Room furnishing. } \\
\text { Guestroom elegance } \\
\text { Luxurious room. } \\
\text { Theme based Guestrooms } \\
\text { Thematic room for women business } \\
\text { travelers } \\
\text { Theme based rooms. } \\
\text { Guestroom Comfort } \\
\text { Business travelers get tired and need } \\
\text { to rest in the room. } \\
\text { Comfort in guestrooms is equally } \\
\text { important. } \\
\text { Warm and inviting. } \\
\text { Comfortable furniture } \\
\text { Comfortable bed. } \\
\text { Room Type } \\
\text { Room preference }\end{array}$ & $\begin{array}{l}\text { Theme: Hotel Services } \\
\text { Codes: } \\
\text { Laundry Service } \\
\text { Ironing of their business attire. } \\
\text { Laundry services required for the } \\
\text { day. } \\
\text { Butler Service } \\
\text { Allocating a female butler. } \\
\text { Butler service for personally taking } \\
\text { care. } \\
\text { Female butler is there to greet them } \\
\text { on arrival and check any special } \\
\text { requirements. } \\
\text { Turndown Service } \\
\text { Specific time of turndown service. } \\
\text { Evening service in guestrooms. } \\
\text { Room Service } \\
\text { Meal plans are taken care in orders } \\
\text { placed through in room dining. } \\
\text { Pre order given to the butler for in } \\
\text { room dining. } \\
\text { Front Office Service } \\
\text { Express check in goes without } \\
\text { saying. } \\
\text { High speed internet service. } \\
\text { Transport Service } \\
\text { Transportation is also carefully } \\
\text { planned. } \\
\text { The way we provide drops and } \\
\text { transport facility. } \\
\text { Organization of airport pick up } \\
\text { Request for the car so we give } \\
\text { emergency numbers of the hotel. }\end{array}$ & $\begin{array}{l}\text { Theme: Amenities } \\
\text { Codes: } \\
\text { Welcome Amenities } \\
\text { Family pictures as welcome } \\
\text { amenities. } \\
\text { Dark chocolate and chocolate } \\
\text { flowers. } \\
\text { Chocolate frames with the picture } \\
\text { of guest. } \\
\text { Special Amenities } \\
\text { Small snack baskets using organic } \\
\text { food ingredients. } \\
\text { Small gestures like placing gold } \\
\text { fish in the guestroom. } \\
\text { Manicure sets. } \\
\text { Special vanity kits for women } \\
\text { travelers having an under-eye } \\
\text { cream, skin toner and moisturizer. } \\
\text { Take away kit as a small gesture. } \\
\text { Regular Amenities } \\
\text { Single lady kits placed in the guest } \\
\text { washrooms. } \\
\text { A mini travelers kit which has a } \\
\text { small bottle of lotion and a small } \\
\text { bottle of skin toner. } \\
\text { Silk bathrobes and scented } \\
\text { candles. } \\
\text { Brand Choice } \\
\text { Specific choice in terms of brands. }\end{array}$ & $\begin{array}{l}\text { Theme: Hotel } \\
\text { Security } \\
\text { Codes: } \\
\text { Room Allocation } \\
\text { Room shouldn't be } \\
\text { blocked close to the } \\
\text { elevator. } \\
\text { Proper room allocation. } \\
\text { Being allocated rooms } \\
\text { near to the elevators and } \\
\text { not just in front of them. } \\
\text { Strategic room location. } \\
\text { Room location has to be } \\
\text { kept in mind. } \\
\text { Safety Features } \\
\text { Call screening } \\
\text { Video cameras installed } \\
\text { on every room door, also } \\
\text { covering the entire hotel } \\
\text { premises } \\
\text { Doorbell camera } \\
\text { Video doorbells } \\
\text { Protective environment } \\
\text { with safety protocols. } \\
\text { Separate floor for women. } \\
\text { Safety in the guestroom. }\end{array}$ \\
\hline
\end{tabular}




\begin{tabular}{|c|c|c|}
\hline $\begin{array}{l}\text { Theme: Augmented Specials } \\
\text { Codes: } \\
\text { Personalized Restaurant Service } \\
\text { Personalized services in the } \\
\text { restaurant. } \\
\text { Female butler personally taking care } \\
\text { of the table. } \\
\text { Delightful meal at the pool side. } \\
\text { Outdoor seating as per their choice } \\
\text { Nice table location which gives a } \\
\text { good view. } \\
\text { Personalized Food Service } \\
\text { Chef on call. } \\
\text { Special master class. } \\
\text { Customizing the menu according to } \\
\text { dietary plans. } \\
\text { Personalized Special Service } \\
\text { Personal preferences before arrival. }\end{array}$ & $\begin{array}{l}\text { Theme: Selection Triggers } \\
\text { Codes: } \\
\text { Location } \\
\text { Hotel location matters to women. } \\
\text { Shopping centers near the hotel. } \\
\text { Price } \\
\text { Pay premium price for comfort. } \\
\text { Price inelastic. } \\
\text { Flexible as far as hotel prices are } \\
\text { concerned. } \\
\text { Money and high price are not so } \\
\text { much of a concern to business } \\
\text { travelers. }\end{array}$ & $\begin{array}{l}\text { Theme: Customized Meal } \\
\quad \text { Requirements } \\
\text { Codes: } \\
\text { Special Food Preferences } \\
\text { Breakfast specials as a part of our } \\
\text { menu. } \\
\text { Special salads. } \\
\text { Light salads. } \\
\text { Gluten free food. } \\
\text { Sugar free food items. }\end{array}$ \\
\hline
\end{tabular}

Table 3. Core Themes Based on Management Perceptions

\begin{tabular}{|c|c|c|c|}
\hline Themes & Sub-Theme & References & $\begin{array}{l}\text { Female symbols } \\
\text { of Expectations }\end{array}$ \\
\hline Guest room & $\begin{array}{l}\text { Guestroom Design and Ambiance, } \\
\text { Theme Based Guest room, Guest room } \\
\text { Comfort, Room type }\end{array}$ & 20 & $\begin{array}{l}\text { Expectation of } \\
\text { Servicescape and } \\
\text { Design }\end{array}$ \\
\hline Hotel Services & $\begin{array}{l}\text { Laundry Service, Butler service, } \\
\text { Turndown service Room Service, Front } \\
\text { Office Service, Transport service }\end{array}$ & 15 & $\begin{array}{l}\text { Expectation of } \\
\text { Comfort }\end{array}$ \\
\hline Amenities & $\begin{array}{l}\text { Welcome, Regular, Special, Amenities, } \\
\text { Brand Choice }\end{array}$ & 12 & $\begin{array}{l}\text { Expectation of } \\
\text { Quality and } \\
\text { Value }\end{array}$ \\
\hline Hotel Security & Room Allocation, Safety Features & 12 & $\begin{array}{l}\text { Expectation of } \\
\text { Assurance and } \\
\text { Trust }\end{array}$ \\
\hline Augmented Specials & $\begin{array}{l}\text { Personalized Restaurant Service, } \\
\text { Personalized Food Service, Personalized } \\
\text { Special Service }\end{array}$ & 9 & $\begin{array}{l}\text { Expectation of } \\
\text { Personalization }\end{array}$ \\
\hline Selection Triggers & Location and Price & 6 & $\begin{array}{l}\text { Expectation of } \\
\text { Convenience and } \\
\text { Suitability }\end{array}$ \\
\hline $\begin{array}{l}\text { Customized Meal } \\
\text { Requirements }\end{array}$ & Special Food Preferences & 5 & $\begin{array}{l}\text { Expectation of } \\
\text { Health and Well- } \\
\text { being. }\end{array}$ \\
\hline
\end{tabular}

Hotel guest rooms emerged as a key theme from the management perspective concerning the expectations of DWBT. The guestroom theme (Table 3) comprising of the guestroom design and ambiance, theme, comfort, and room type depicts the female symbol of expectation as the "Expectation of servicescape and design." Since business trips are stressful, guestroom features that enhance relaxation are significant for business travelers. A well-designed guestroom encompasses a holistic blend of the components and standards of design. A true expression of a hotel's service spirit is conveyed through a feel-good, aesthetically appealing, and comfortable décor. The ambiance and décor act as physical evidence as 
signs offering judgment concerning the care and thoughtfulness of a hotel for the DWBT. The findings are concurrent with previous findings which cited those well-designed aesthetic aspects create lasting emotional responses amongst hotel guests (Kim \& Perdue, 2013; Lockwood \& Pyun, 2019; Walls et al., 2011). Comfortable and elegant guestrooms are a part of the core service element for business travelers (Babakus et al., 2005; Choi \& Chu, 2001; Chung et al., 2004; Mao et al., 2018; Ogle, 2009; Wang et al., 2020). Feelings of comfort are valued by women business travelers (Brownell, 2011), thus retaining the guestrooms as an essence for hotel selection. In this regard P2 specifically mentioned:

"We have thematic guestrooms for the domestic women business travelers. Guestroom design and décor have a long-lasting impact on the satisfaction of women business guests. We take care of the same in our hotel."

The theme- hotel services (Table 3), comprising laundry, butler, turndown, room, front office, and transport services depicts the female symbol of expectation as "Expectation of comfort." Services offered by luxury hotels are valued by women guests while impacting their hotel selection decision as well (Ariffin \& Maghzi, 2012; Hao \& Har, 2014). The study reveals that DWBT construe the quality of services and facilities offered as the hotel's concern for their comfort and well-being. Moreover, the concern is also judged by DWBT from the variety of hotel offerings to accommodate their unique requirements. These services provided by the hotels add to the feeling of comfort by taking away the pain of "making an effort" by women guests. These services are symbolized as expectations because the guest is taken care of, is understood, and valued. P9 voiced a similar opinion on the services provided to DWBT:

"People traveling away from home staying in hotels for business tend to feel lonely and expect the hotel to look after them. Women business travelers are just looking for an assurance that they are being valued and cared for."

The amenities theme (Table 3) comprising of welcome, regular, and special amenities, with the brand choice depicts the female symbol of expectation as "Expectation of quality and value." Women travelers always value the spectrum of amenities offered to them during their stay (Howell et al., 1993; Juwaheer, 2011; Marzuki et al., 2012; Khoo-Lattimore et al., 2018). Branded personal care products given by luxury hotels are reminisced by the women guests (Heo \& Hyun, 2015). The presentation, packaging, and placement of amenities are vital to enrich the tangible aspects by appealing to women guests' feeling of aesthetics. Being thoughtful towards the provision of in-room amenities amalgamated with 
the guestroom design helps in reducing stress while enhancing the relaxation of DWBT by offering sensory enjoyment and pleasure. Cetin and Walls (2016) mentioned that the décor, ambiance, amenities, interaction with professional and attentive hotel staff are the facets imperative for creating a positive guest experience in a luxury hotel. About the importance of amenities, P5 stated:

"I think the smallest things like the amenities have a big role to play once women are alone._They can help in revitalizing their mood."

The Hotel Security theme (Table 3) comprising of room allocation and safety features signifies the female symbol of expectation as "Expectation of assurance and trust." Feeling safe is a fundamental emotion when women travel independently (Brownell, 2011; Wilson \& Little, 2008). Regardless of the purpose of travel, business travelers place a lot of emphasis on hotel safety (McCleary et al., 1994). Previous studies have accentuated the importance of hotel safety and security features for women travelers (Feickert et al., 2006; Hao \& Har, 2014).

Having a safe and secure environment without any worry of threats throughout the stay is an expectation that needs to be acknowledged. Equally vital is to lessen the unease felt by DWBT while using the public area facilities like the bar or restaurant. P12 poured out her thoughts regarding the safety of women business travelers by mentioning:

"When it comes to women business travelers, the stakes are higher. If women business travelers start choosing a particular hotel, it will showcase their trust in terms of safety and security".

P4 put forth the efforts taken by hoteliers to ensure the safety of DWBT:

"We have video cameras which are installed on every room door along with the doorbell so that there is a two-way communication before they open the door. In case of an emergency, we have the speed dial numbers of the duty managers available on the landline of the guestrooms".

P7 supported his fellow participant by stating:

"Safety and security are important, and we have special provisions for women business travelers. Allocation of rooms is done properly; room location has to be kept in mind with express check-in and check-out facility. Also, video cameras are covering the entire hotel premises."

Generating satisfaction amongst DWBT through memorable experiences is significant for the hospitality industry. Therefore, the fifth 
identifiable theme has been cited as augmented specials. The Augmented Specials theme (Table 3) comprising of personalized restaurant service, personalized food service, and personalized special service symbolize the expectations of women as "Expectation of personalization." Devoting attention to the personal preferences of making arrangements that cater to the needs and desires of the women business travelers before her arrival augment the feeling of being acknowledged as a valued guest by the hotel. Making the business trip more stimulating through the involvement of women business guests in stress-relieving activities like yoga, aerobics, and cookery classes with master chefs can be used as a means to connect and develop bonds with them. The findings are in accord with the work of Cetin and Walls (2016) where the authors concluded that exceeding guest expectations are crucial for guest satisfaction and loyalty. Pragmatic and first-hand experiences through guest involvement can help hotels in developing an emotional connection with the women business guests. P3 detailed the significance of delivering personalized services through female staff:

"We prefer female staff for handling women business travelers to give them a sense of comfort and a sense of belonging to that place. The moment they come out of the flight and see a woman chauffeur standing for them, it's like a comfort factor for them. Then in our hotel, we also arrange women-only staff for the check-in, butler service, in-room dining, and housekeeping".

Grounded on the responses received, selection triggers formed the sixth theme encompassing hotel location and price. The selection triggers (Table 3) depict a symbol of expectation for women as "Expectation of Convenience \& Suitability." Convenient transport service and an advanced location can help a hotel attract female customers traveling (Liu et al., 2013). Price is an important factor to consider since it has a complex association with accommodation selection because hotel selection based on the preferred location may mean paying a higher price at times (Baruca \& Civre, 2012; Lockyer, 2005b). Carefully planned transportation services for DWBT to their workplace where female executives can accompany them or especially available transport by female chauffeurs can augment the feeling of being taken care of by the hotels. Similarly, offering shuttle bus services to various recreational and shopping centers or city center locations can provide a competitive edge to hotels. DWBT making frequent business trips to similar destinations must feel at ease with the hotel employees and environment to select the same hotel for their stay.

The customized meal requirements theme incorporating special food preferences depict the symbol of expectation for women as "Expectation of 
health and well-being" since nutritious and wholesome food is important for women business travelers. These findings are similar to the findings of previous researchers (Chen, 2019; Khoo-Lattimore et al., 2018). Menu designing and planning for restaurants and room service, healthy and light menu options, the taste of food, efficient service by skilled staff, and value for money are a few expectations of women business travelers. Adding on a surprise organic food preparation, customized as per the taste and preference when room service is selected, can add to an element of surprise for the women business guest. Restaurant dining experiences for DWBT can be enhanced by offering flexibility in portion sizes of food items so that the women business guests can taste various dishes. P7 shared his thoughts by stating:

"Guests are having special dietary requirements like the keto or paleo diet so they prefer having specific meals according to the particular diet plan they are having. Therefore, to follow that we ensure that the ingredients used are mentioned prior to the preparation of food."

\section{CONCLUSION}

Qualitative studies using online data collections have gained popularity in recent times where the generalizability of findings is not the key motive. As stated by Austin and Sutton (2014, p. 436), "Practitioners do not seek to generalize their findings to a wider population. Rather, they attempt to find examples of behavior, to clarify the thoughts and feelings of study participants, and to interpret participants' experiences of the phenomena of interest, to find explanations for human behavior in a given context".

The findings demonstrated by this research are in agreement with the factors that are rated important for business guests (Baruca \& Civre, 2012; Hao \& Har, 2014; Khoo-Lattimore et al. 2018; Kim et al., 2019; Lockyer, 2005a; Mao et al., 2018; Wang et al., 2020). The study symbolizes these factors with expectations for domestic women business travelers as the expectation of servicescape and design, the expectation of comfort, the expectation of quality and value, the expectation of assurance and trust, the expectation of personalization, expectation of convenience, and suitability and, expectation of health and well-being. Defining these expectations is important because satisfaction and repeat purchase intention can be achieved through fulfilling the needs and desires of guests.

This exploratory research is the first to break new ground to assess findings using synchronous FGDs for understanding expectations of 
women business travelers from the management perspective. Through a relatively unmapped research method for understanding hotel management perceptions using the synchronous FGDs technique, this research assists in making a skillful effort to the existing hospitality literature. Lastly, the focus of the study pertains to the context of the Indian hotel industry, making it a crucial and distinguishing aspect whereas the theoretical and managerial contribution should be assessed as an essential input in the country's milieu.

\section{Theoretical Implications}

This study adds to the prevailing literature of the perception of hotel managers on expectations of female business travelers. By building on expectancy disconfirmation theory (Oliver, 1980) the study establishes DWBTs' expectations work as a forecast of hotels' future performance by anticipating and incorporating their needs. The study concurs with Oliver's (1980) theory as hotel managers who participated in the FGDs reiterated that services, experiences, and products fulfilling high expectations are predicted to generate more satisfaction than services, experiences, and products meeting lower expectations. The study puts forth the high quality of service and guest experiences since the hotel managers tend to overvalue guests' expectations (Radder, 2006). Such discussions of high quality associated with service and guest experiences will not only elevate the standard of hotel practices but also add to the theory for superior learning and development for both industry and academia.

\section{Practical Implications}

With a constant rise in the number of women who travel for work (Brownell, 2011), hotels need to be familiar with their complex decisionmaking process related to hotel selection. Enhancing the hotel offerings to create an experiential stay should align with the concerns of DWBT. Cetin et al. (2014) demonstrated that creating value from the customer perspective is essential for organizations aspiring to craft guest experiences. Hotel managers should focus on creating exceptional experiences for the guests through an appropriate amalgamation of organizational resources.

Hotels should be a sort of home office for the DWBT during their trip. Strengthening aspects that augment the sense of comfort, well-being, and relaxation which help the women guests adapt to the new hotel environment without unease should be focused upon. The concern of care should be visible and communicated through the tangible aspects and 
intangible service processes of a hotel. Functional, sensory, and resultoriented processes should be integrated to craft memorable experiences for the DWBT.

Concerning hotel attributes, the factor guestroom concerning comfort is of utmost significance. Since women face travel-related stress associated with maintaining a work-life balance (Moser, 2021), hotels should emphasize engendering feelings of comfort during their stay. Guestroom design and ambiance should be given utmost attention. Regular updates, maintenance and renovation should be undertaken and a budget should be allocated for the same. Improvements and innovations in the guestroom design through a careful blend and contrast of interiors for creating the ambiance of theme-based guestrooms can help in enhancing the sense of relaxation. Proper placement and planning of lighting sources can be taken care of through easily accessible switches while designing the guestroom. A well-planned work setup offering convenience through prominently positioned electricity sockets, work-light, and a comfortable chair add an essence to the rooms allocated to DWBT. Hotels can even create a relaxation den in the guestroom by offering comfortable couches, rocking chairs, or arm-chairs where women can retreat after a hectic day of work. Spacious guestrooms with large windows with a good view, provision of extra shelves in the bathroom for keeping makeup, accessories, and clothes are a few functional aspects that can be incorporated in the guestroom design and layout.

Experience-oriented services should be designed to fulfill the functional value while evoking an affective response amongst the DWBT. Hotels can offer personal women staff assistant services to DWBT during their business trips. These female assistants can help with business center facilities, getting the attire ready for meetings, assist in tailor services in case needed, or even interact with chefs/restaurant staff on behalf of the women business guests for the provision of special seating requirements during meals. Customized services designed to create "moments of wow" for delivering a seamless experience to the women business guests can offer differentiation to hotels. Clothing items can be readied and kept in the guestroom for women business travelers before they leave for meetings. Replenishment of the minibar fridge in the guestroom with the women guests' favorite drinks keeping in mind the health-conscious aspect is another custom-made service that can be offered by hotels.

The amenities should be decided upon with utmost care and regular feedback on the same should be taken. The quality, brand, packaging and 
placement have an enormous appeal for DWBT. Focusing on the aesthetic aspect of the in-room amenities is a factor of key significance especially for the DWBT. Hotels can go the extra mile by providing a premium tea/coffee collection, full-length mirrors, two-sided magnifying mirrors in the bathroom, hair straighteners, silk bathrobes, plush bath linen to make them feel 'cared for' during their stay. Welcome messages on behalf of the hotel, personalized messages signed by the housekeeper during the turndown service can work as a warranty for service quality.

Safety and security are always a matter of concern for women travelers. Assuring the DWBT of safety and security by incorporating high vigilance and care for privacy during check-in and check-out, screening of calls and visitors, extra security on floors with cameras, alarms in the guestroom and the bathroom, elevator access to the floors through keycards, interactive doorbells would help convey the message of care to the DWBT.

Women nowadays are fitness enthusiasts, also believing in natural remedies and mind relaxation (Lee et al., 2019). Introducing planned yoga and aerobic sessions are great means for the DWBT to relax and rejuvenate. Light and low fat/low-calorie food can be packed and offered to the women guests on the go. Cocktail services provided to DWBT in the comfort of their rooms can be another added feature.

Incorporation of local art, design, and architecture can be more fulfilling experientially for DWBT. Hoteliers need to enhance the practical aspect of the facilities in sync with the interior design for comfort, convenience, accessibility, and ease of use for the DWBT. Minimizing effort and increasing user-friendliness enhances the guest's comfort.

\section{Limitations and Future Research}

The study is not free from limitations while providing directions for future research. The researchers have adopted the qualitative analysis of data gathered through synchronous focus groups conducted for the management personnel of the hotel industry; generalization of results may not be justifiable. A lot of technical issues were faced by the participants while the FGDs were conducted. The study has explored a single side of the coin by accumulating views of hotel managers only. Another limitation of the study is that these perceptions pertain to the Indian context, where the focus group participants belonged to the five-star hotels located in Delhi and Gurugram, and the discussion pertained to only one market segment 
of hotel guests. Replicating the study in different cultural and geographical settings for different guest segments may generate newer findings while revealing different themes. Further empirical investigations with a larger sample size, based on rigorous data analysis exploring the sub-themes and core themes, would be beneficial where management perceptions and the expectations of DWBT can be evaluated and explored to narrow down the prevalent gaps.

\section{REFERENCES}

Ariffin, A. A., \& Maghzi, A. (2012). A preliminary study on customer expectations of hotel hospitality: Influences of personal and hotel factors. International Journal of Hospitality Management, 31, 191-198. doi:10.1016/j.ijhm.2011.04.012.

Auld, G. W., Boushey, C. J., Cluskey, M., Misner, S. L., \& Wang, C. (2007). Development of a decision tree to determine appropriateness of NVivo in analyzing qualitative data sets. Journal of Nutrition, Education and Behavior, 39(1), 37-47. doi:10.1016/j.jneb.2006.09.006.

Austin, Z., \& Sutton, J. (2014). Qualitative research: Getting started. The Canadian Journal of Hospital Pharmacy, 67(6), 436-440.

Babakus, E., Yavas, U., \& Eroglu, S. (2005). Gender effects on relational and core service dimensions of hotel choice decisions. Journal of Relationship Marketing, 4(1-2), 3-20. doi: 10.1300/J366v04n01_02.

Baruca, P., \& Civre, Z. (2012). How do guests choose a hotel? Academica Turistica, 5(1), 7584.

Blackwell, D. R., Miniard, P. W., \& Engel, J. F. (2006). Consumer Behaviour (10th edition). Mason: Thomson South-Western.

Blesic, I., Ivkov-Dţigurski, A., Stankov, U., Stamenkoviš, I., \& Bradiš, M. (2011). Research of expected and perceived service quality in hotel management. Journal of Tourism, 11, 5-13.

Braun, V., \& Clarke, V. (2006). Using thematic analysis in psychology. Qualitative Research in Psychology, 3(2), 77-101.

Brownell, J. (2011). Creating value for women business travelers: focusing on emotional outcomes. Cornell Hospitality Report, 11(12), 6-17.

Bryman, A. (2012). Social research methods. Oxford; New York: Oxford University Press.

Cetin, G. (2020). Experience vs quality: predicting satisfaction and loyalty in services. The Service Industries Journal, 40(15-16), 1167-1182. doi:10.1080/02642069.2020.1807005.

Cetin, G., \& Walls, A. (2016). Understanding the customer experiences from the perspective of guests and hotel managers: empirical findings from luxury hotels in Istanbul, Turkey. Journal of Hospitality Marketing \& Management, 25(4), 395-424 doi:10.1080/19368623.2015.1034395.

Cetin, G., Akova, O., \& Kaya, F. (2014). Components of experiential value: case of hospitality industry. Procedia - Social and Behavioral Sciences, 150, 1040-1049.

Chan, E. S., \& Lam, D. (2013). Hotel safety and security systems: bridging the gap between managers and guests. International Journal of Hospitality Management, 32, 202-216. doi: 10.1016/j.ijhm.2012.05.010.

Chan, E. S., \& Wong, S. C. (2006). Hotel selection: When price is not the issue. Journal of Vacation Marketing, 12(2), 142-159.

Chen, H. S. (2019). A pilot study of business travelers' stress-coping strategies. Tourism and Hospitality Research, 19(2), 252-258. 
Choi, T. Y., \& Chu, R. (2001). Determinants of hotel guests' satisfaction and repeat patronage in the Hong Kong hotel industry. International Journal of Hospitality Management, 20(3), 277-297.

Chung, K. Y., Oh, S. Y., Kim, S. S., \& Han, S. Y. (2004). Three representative market segmentation methodologies for hotel guest room customers. Tourism Management, 25(4), 429-441.

Cobanoglu, C., Corbaci, K., Moreo, P. J., \& Ekinci, Y. (2003). A comparative study of the importance of hotel selection components by Turkish business travelers. International Journal of Hospitality $\mathcal{E}$ Tourism Administration, 4(1), 1-22. doi: 10.1300/J149v04n01_01.

Creswell, J. W. (2007). Qualitative inquiry and research design: Choosing among five approaches. Thousand Oaks: Sage Publications.

Deng, W.-J., Kuo, Y.-F., \& Chen, W.-C. (2008). Revised importance-performance analysis: three-factor theory and benchmarking. The Service Industries Journal, 28(1), 37-51. doi:10.1080/02642060701725412.

Feickert, J., Verma, R., Plaschka, G., \& Dev, C. S. (2006). Safeguarding your customers: The guest's view of hotel security. Cornell Hotel and Restaurant Administration Quarterly, 47(3), 224-244.

Garcia, M. (2014). The rise of female business travelers. New York: Skift Research.

Gumaste, R. R. (2019). A study of preferences of in-room facilities by female business travelers in hotels (with special reference to 5 star business hotels in Pune city). International Journal of Research and Analytical Reviews, 6(1), 63-67.

Gummesson, E. (2000). Qualitative methods in research management (2nd Ed.). California: Sage.

Hao, J. S., \& Har, C. O. (2014). A study of the preferences of business female travelers on the selection of accommodation. Procedia-Social and Behavioral Sciences, 144, 176186.

Hennink, M. M. (2014). Understanding focus group discussions. New York: Oxford University Press.

Heo, C., \& Hyun, S. S. (2015). Do luxury room amenities affect guests' willingness to pay? International Journal of Hospitality Management, 46, 161-168 doi: 10.1016/j.ijhm.2014.10.002.

Hinkes, C. (2021). Key aspects to consider when conducting synchronous text based online focus groups- a research note. International Journal of Social Research Methodology, 24(6), 753-759. doi: 10.1080/13645579.2020.1801277.

Howell, R. A., Moreo, P. J., \& DeMicco, F. J. (1993). A qualitative analysis of hotel services desired by female business travelers. Journal of Travel and Tourism Marketing, 1(4), 115-132.

Hu, F., \& Trivedi, R. (2020). Mapping hotel brand positioning and competitive landscapes by text-mining user-generated content. International Journal of Hospitality Management 84, 102317.

Hussain, S., \& Khanna, K. (2019). Guest satisfaction: A comparative study of hotel employees' and guests' perception. International Journal of Hospitality and Tourism Systems, 12(1), 83-93.

Hussain, S. (2017). Guest satisfaction in the 5 star deluxe hotel of Delhi determinants and challenges. Unpublished doctoral dissertation, Amity School of Hospitality, Noida, U.P.. Retrieved from http://hdl.handle.net/10603/189029 
Iacobucci, D., \& Ostrom, A. (1993). Gender differences in the impact of core and relational aspects of services on the evaluation of service encounters. Journal of Consumer Psychology, 2(3), 257-286.

Juwaheer, T. D. (2011). Gender bias in hotel guests' perceptions of service quality: An empirical investigation of hotels in Mauritius. e-Review of Tourism Research, 9(5), 164-189.

Khanna, A., \& Tyagi, G. (2019). The 2019 Indian Hospitality Trends \& Opportunities Report. New Delhi: Hotelivate.

Khoo-Lattimore, C., Prayag, G., \& Disegna, M. (2018). Me, my girls, and the ideal hotel: Segmenting motivations of the girlfriend getaway market using fuzzy C-medoids for fuzzy data. Journal of Travel Research, 58(5), 774-792.

Kim, B., Kim, S., King, B. E., \& Heo, C. Y. (2019). Luxurious or economical? An identification of tourists' preferred hotel attributes using best-worst scaling (BWS). Journal of Vacation Marketing, 25(2), 162-175.

Kim, D., \& Perdue, R. R. (2013). The effects of cognitive, affective, and sensory attributes on hotel choice. International Journal of Hospitality Management, 35, 246-257. doi: 10.1016/j.ijhm.2013.05.012.

Kim, D., Hong, S., Park, B.-J., \& Kim, I. (2020). Understanding heterogeneous preferences of hotel choice attributes: Do customer segments matter?. Journal of Hospitality and Tourism Management, 45, 330-337. doi: 10.1016/j.jhtm.2020.08.014.

Kim, Y. (2018). Power moderates the impact of desire for exclusivity on luxury experiential consumption. Psychology \& Marketing, 35(4), 283-293. doi:10.1002/mar.21086

King, C., \& Grace, D. (2008). Internal branding: Exploring the employee's perspective. Journal of Brand Management, 15(5), 358-372. doi:10.1080/10548408.2011.588108.

Kitzinger, J. (1994). The methodology of focus groups: The importance of interaction between research participants. Sociology of Health, 16(1), 103-121.

Lee, P. C., Lee, M. J., \& Cheng, T.-T. (2019). Importance of wellness concepts in the hotel industry: Perspectives from the millennials. Journal of Quality Assurance in Hospitality and Tourism, 20(6), 729-752. doi:10.1080/1528008X.2019.1616041.

Lester, S. (1999). An introduction to phenomenological research. Taunton UK: Stan Lester Developments.

Liu, S., Law, R., Rong, J., Li, G., \& Hall, J. (2013). Analyzing changes in hotel customers' expectations by trip mode. International Journal of Hospitality Management, 34, 359371. doi: 10.1016/j.ijhm.2012.11.011.

Lobe, B. (2017). Best practices for synchronous online focus groups. In R. S. Barbour, \& D. L. Morgan (Eds), A New Era in Focus Group Research (pp. 227-250). London: Palgrave Macmillan.

Lockwood, A., \& Pyun, K. (2019). How do customers respond to the hotel servicescape? International Journal of Hospitality Management, 82, 231-241. doi: 10.1016/j.ijhm.2019.04.016 .

Lockyer, T. (2002). Business guests' accommodation selection: The view from both sides. International Journal of Contemporary Hospitality Management, 14(6), 294-300. doi: $10.1108 / 09596110210436832$.

Lockyer, T. (2005a). The perceived importance of price as one hotel selection dimension. Tourism Management, 26(4), 529-537.

Lockyer, T. (2005b). Understanding the dynamics of the hotel accommodation purchase decision. International Journal of Contemporary Hospitality Management, 17(6), 481492 doi: 10.1108/09596110510612121. 
Luk, S. T., \& Layton, R. (2002). Perception gaps in customer expectations: Managers versus service providers and customers. The Service Industries Journal, 22(2), 109-128.

Maguth, B. M., \& Yamaguchi, M. (2020). Lessons from A-bomb survivors: Researching Hiroshima \& Nagasaki survivors perspectives for use in U.S. social studies classrooms. The Journal of Social Studies Research, 44(4), 325-338. doi: 10.1016/j.jssr.2020.03.002.

Mao, Z., Yang, Y., \& Wang, M. (2018). Sleepless nights in hotels? Understanding factors that influence hotel sleep quality. International Journal of Hospitality Management, 74, 189-201.

Marzuki, A., Chin, T. L., \& Razak, A. A. (2012). What women want: Hotel characteristics preferences of women travellers. In M. Kasimoglu, \& H. Aydin (Eds), Strategies for Tourism Industry - Micro and Macro Perspectives (pp. 143-164). Rijeka: InTechopen.

Masiero, L., Yang, Y., \& Qiu, R. T. (2019). Understanding hotel location preference of customers: Comparing random utility and random regret decision rules. Tourism Management, 73, 83-93. doi: 10.1016/j.tourman.2018.12.002.

McCleary, K. W., Weaver, P. A., \& Lan, L. (1994). Gender based differences in business travelers' lodging preferences. The Cornell Hotel and Restaurant Administration Quarterly, 35(2), 51-58.

Mcintosh, A. J., \& Siggs A. (2005) An exploration of the experiential nature of boutique accommodation. Journal of Travel Research, 44(1), 74-81. doi: $10.1177 / 0047287505276593$

Meng, F., \& Uysal, M. (2008). Effects of gender differences on perceptions of destination attributes, motivations, and travel values: An examination of a nature-based resort destination. Journal of Sustainable Tourism, 16(4), 445-466. doi: 10.1080/09669580802154231.

Michel, S. (2001). Analyzing service failures and recoveries: A process approach. International Journal of Service Industry Management, 12(1), 20-33.

Mohsin, A., Rodrigues, H., \& Brochado, A. (2019). Shine bright like a star: Hotel performance and guests' expectations based on star ratings. International Journal of Hospitality Management, 83, 103-114. doi:10.1016/j.ijhm.2019.04.012.

Morgan, D. L. (1997). Focus Groups as Qualitative Research (2nd ed.). Thousand Oaks, CA: Sage Publications.

Moser, T. (2021). Work life balance of female international business travelers. Retrieved March 1, 2021, from https://osuva.uwasa.fi: https://osuva.uwasa.fi/bitstream/handle/10024/12359/UniVaasa_2021_Tanja_Mos er.pdf? sequence $=2 \&$ isAllowed $=y$

Newth, F. (2009). The new strategic imperative: Understanding the female business traveler. International Business and Economics Research Journal, 8(11), 51-64. doi: 10.19030/iber.v8i11.3185.

Ogle, A. (2009). Making sense of the hotel guestroom. Journal of Retail \& Leisure Property, 8 , 159-172. doi: 10.1057/rlp.2009.7.

Oliver, R. L. (1980). A cognitive model of the antecedents and consequences of satisfaction decisions. Journal of marketing research, 17(4), 460-469.

Radder, L., \& Wang, Y. (2006). Dimensions of guest house service managers' perceptions and business travellers' expectations. International Journal of Contemporary Hospitality Management, 18(7), 554-562. doi: 10.1108/09596110610702986

Richard, B., Sivo, S., Orlowski, M., Ford, R., Murphy, J., Boote, D., \& Witta, E. (2018). Online focus groups: a valuable alternative for hospitality research. International Journal of 
Contemporary Hospitality Management, 30(11), 3175-3191. doi: 10.1108/IJCHM-112017-0715.

Richards, L. (2005). Handling Qualitative Data: A Practical Guide. London: Sage.

Rohani, L. S., Aung, M., \& Rohani, K. (2017). Customer preferences toward hotel facilities and service quality: A cross-cultural analysis. International Review of Business Research Papers, 13(1), 78-87. doi: 10.21102/irbrp.2017.03.131.06.

Sánchez-Franco, M. J., Navarro-García, A., \& Rondán-Cataluña, F. J. (2018). A naive Bayes strategy for classifying customer satisfaction: A study based on online reviews of hospitality services. Journal of Business Research, 101, 499-506. doi: 10.1016/j.jbusres.2018.12.051.

Seal, P. P., Devija, P., \& Kumaran, P. S. (2018). Employee engagement in hotels: Comparison between a four star and a five star hotel in Kolkata. Management Today, 8(1), 76-80.

Salleh, M. Z. M., Said, A. M., Bakar, E. A., Ali, A. M., \& Zakaria, I. (2016). Gender differences among hotel guest towards dissatisfaction with hotel services in Kuala Lumpur. Procedia Economics and Finance, 37, 27-32. doi: 10.1016/S22125671(16)30088-0

Tewari, J. R. (2009). Hotel Front Office: Operations and Management. Oxford University Press. Thyme, K., Wiberg, B., Lundman, B., \& Graneheim, U. (2013). Qualitative content analysis in art psychotherapy research: concepts, procedures, and measures to reveal the latent meaning in pictures and the words attached to the pictures. Arts Psychother, 40(1), 101-107. doi: 10.1016/j.aip.2012.11.007.

Tsai, H., Yeung, S., \& Yim, P. (2011). Hotel selection criteria used by Mainland Chinese and foreign individual travelers to Hong Kong. International Journal of Hospitality $\mathcal{E}$ Tourism Administration, 12(3), 252-267. doi: 10.1080/15256480.2011.590738.

Tsang, N. K., Lee, L. Y., \& Li, F. X. (2011). An examination of the relationship between employee perception and hotel brand equity. Journal of Travel \& Tourism Marketing, 28(5), 481-497. doi:10.1080/10548408.2011.588108.

Umasuthan, H., Park, O.-J., \& Ryu, J.-H. (2017). Influence of empathy on hotel guests' emotional service. Journal of Services Marketing, 31(6), 618-635. doi:10.1108/JSM-062016-0220.

Urry, J. (1991). The Tourist Gaze. London, Newbury Park, CA, New Delhi: Sage.

Walls, A. R., Okumus, F., Wang, Y., \& Kwun, D. J.-W. (2011). Understanding the consumer experience: An exploratory study of luxury hotels. Journal of Hospitality Marketing and Management, 20(2), 166-197.

Wang, L., Wang, X. K., Peng, J.-J., \& Wang, J. Q. (2020). The differences in hotel selection among various types of travellers: A comparative analysis with a useful bounded rationality behavioral decision support model. Tourism Management, 76, 103961. doi: 10.1016/j.tourman.2019.103961.

Wilson, E., \& Little, D. E. (2008). The solo female travel experience: Exploring the 'geography of women's fear'. Current Issues in Tourism, 11(2), 167-186.

Wu, H., Liao, H.-C., Hung, K.-P., \& Ho, Y. H. (2012). Service guarantees in the hotel industry: Their effects on consumer risk and service quality. International Journal of Hospitality Management, 31(3), 757-763. doi: 10.1016/j.ijhm.2011.09.012.

Zeithaml, V. A., Bitner, M. J., \& Gremler, D. D. (2006). Services Marketing. Integrating Customer Focus Across the Firm (4th ed.). New York: McGraw-Hill.

Zikmund, W. G. (2003). Sample Designs and Sampling Procedures. Cincinnati: OH: Thomson/South-Western. 